East African Medical Journal Vol. 86 No. 7 July 2009

KNOWLEDGE OF GENITAL HERPES INFECTION AMONG ANTENATAL CLINIC ATTENDEES IN SOUTHEASTERN NIGERIA

S. Onwere, MBChB, MMed (Obst. \& Gynae), Senior Lecturer, B. Chigbu, MBBS, FWACS, Lecturer, O. Okoro, MBBS, FWACS, FRCOG, Senior Lecturer, C. I. Kamanu, MBChB, FW ACS, Senior Lecturer, C. Aluka, MBBS, FWACS, FRCOG, Senior Lecturer, Department of Obstetrics and Gynaecology, Abia State University Teaching Hospital, P.M.B. 7004, Aba, Abia State, Nigeria. and A. Onwere, MBBS, Department of Primary Healthcare', Aba South Health Office, Aba, Abia State, Nigeria

Request for reprints to: Dr. S. Onwere, Department of Obstetrics and Gynaecology, Abia State University Teaching Hospital, P.M.B. 7004, Aba, Abia State, Nigeria

\title{
KNOWLEDGE OF GENITAL HERPES INFECTION AMONG ANTENATAL CLINIC ATTENDEES IN SOUTH-EASTERN NIGERIA
}

\author{
S. ONWERE, B. CHIGBU, O. OKORO, C. I. KAMANU, C. ALUKA, and A. ONWERE
}

\begin{abstract}
Background: Herpes simplex virus (HSV) is a major cause of genital ulcer disease worldwide and a significant factor for increased risk of acquisition and transmission of the Human Immune Deficiency Virus (HIV). The determination of the level of knowledge of genital herpes is necessary for the design and implementation of its specific preventive strategies as well as the reduction of the contribution of genital herpes to HIV transmission.

Objective: To determine antenatal women's knowledge on genital herpes infection. Design: A cross sectional descriptive study.

Setting: Antenatal clinic of Abia State University Teaching, Hospital, Aba, Nigeria. Subjects: Three hundred and fifty consecutive and consenting antenatal clinic attendees of Abia State University Teaching Hospital (ABSUTH), Aba, South Eastern, Nigeria. Results: Seventy nine respondents $(22.6 \%)$ had ever heard of genital herpes whilst sixty two $(17.7 \%)$ had ever had recurrent blisters around their genitals. Two hundred and sixteen respondents $(61.7 \%)$ reported having had cold sores or blisters around the lips or mouth following an episode of fever. Seventy four $(21.1 \%)$ of the respondents knew that the virus that causes cold sores or blisters can be sexually transmitted. Higher educational levels attained and occupations other than being a housewife or farmer were associated with a greater awareness of genital herpes $(p<0.05)$ among the subjects.

Conclusion: The antenatal attendees showed a poor knowledge of genital herpes infection. Discussion of genital herpes should be considered in the antenatal clinic setting along with the counselling of pregnant women regarding genital herpes, HIV infection and maternal-to-child transmission of both HSV and HIV.
\end{abstract}

\section{INTRODUCTION}

Herpes simplex virus (HSV) is a highly prevalent sexually transmitted infection (STI) that results in genital herpes. The majority of infections are caused by HSV type 2 (HSV -2), although genital infections with HSV type 1 (HSV -1) are not uncommon (1). HSV-2 is a major cause of genital ulcer disease in sub-Saharan Africa, where HSV-2 seroprevalence among sexually active adults ranges from 50\% to $90 \%$ (2). Genital ulcers have been associated with an approximately threefold increase of sexual HIV-1 transmission (3). HSV 1 and 2 can also be transmitted to the neonate, particularly in primary maternal infection. Significant mortality and morbidity are associated with neonatal infections (1). Thus, genital herpes is a disease of major clinical importance. The determination of the level of knowledge of genital herpes is necessary for the design and implementation of specific prevention strategies as well as the reduction of the contribution of genital herpes to HIV transmission. However, very few studies on knowledge of genital herpes have been done in our region. This study aims to examine the level of knowledge of genital herpes infection in the resource restricted setting of Aba, South Eastern Nigeria. The results of the study will be useful for those counselling pregnant women regarding HSV and other STIs, the synergistic relationship between ulcerative STIs such as genital herpes and transmission of HIV, as well as the maternal-to-child transmission of both HSV and HIV. Hence, the need for this study. 


\section{MATERIALS AND METHODS}

This was a hospital based study that was carried out between $1^{\text {st }}$ July, 2008 and $1^{\text {st }}$ September, 2008 at the antenatal clinic of Abia State University Teaching Hospital, Aba. Three hundred and fifty consecutive antenatal clinic attendees who gave informed consent to participate in the study were enrolled. A structured questionnaire developed by the authors was administered to elicit demographic data and knowledge of genital herpes infection. The wordings of the questionnaire were explained to the respondents in the vernacular for easier comprehension. Data analysis included descriptive statistics for demographic data and content analysis for interview data. Using Epi Info version 6, statistical comparisons were made using the Chi square test with Yates correction or Fischer's exact test as appropriate. P-value of $<0.05$ was considered significant.

Ethical approval was obtained from the Ethical and Research Committee of Abia State University Teaching Hospital, Aba.

\section{RESULTS}

Three hundred and fifty consecutive antenatal clinic attendees were recruited for the study. Table 1 shows the socio-demographic characteristics. The average age of the subjects was 31.2 years. The majority $(98.2 \%)$ were married. Seventy nine $(22.6 \%)$ of respondents had ever heard of genital herpes whilst sixty two $(17.7 \%)$ had ever had recurrent blisters around their genitals. Two hundred and sixteen of the respondents $(61.7 \%)$ reported having had cold sores or blisters around thelips or mouth following an episode of fever. Seventy four $(21.1 \%)$ knew that the virus that causes cold sores or blisters can be sexually transmitted (Table 2). Higher educational levels attained and occupations other than being a farmer or housewife were associated with a greater awareness of genital herpes among the subjects $(\mathrm{p}<0.05)$ (Table 3$)$.

Table 1

Socio-demographic characteristics of respondents

\begin{tabular}{lcc}
\hline Characteristic & No. & $(\%)$ \\
\hline Age in years & & \\
$\leq 19$ & 1 & 0.3 \\
$20-29$ & 121 & 34.6 \\
$30-39$ & 222 & 63.4 \\
$40-49$ & 6 & 1.7 \\
Marital status & & \\
Married & 344 & 98.2 \\
Single & 3 & 0.9 \\
Divorced & 3 & 0.9 \\
Educational level & & \\
Primary & 9 & 2.5 \\
Secondary & 191 & 54.6 \\
Post secondary & 150 & 42.9 \\
Parity & & \\
0 & 1 & 0.3 \\
1 & 26 & 7.4 \\
2 & 170 & 48.6 \\
3 & 106 & 30.3 \\
4 & 34 & 9.7 \\
5 & 8 & 2.3 \\
6 & 4 & 1.1 \\
$\geq 7$ & 1 & 0.3 \\
\hline
\end{tabular}


Table 2

Knowledge of genital herpes

\begin{tabular}{lcc}
\hline Variable & No. & $(\%)$ \\
\hline Ever heard of genital herpes & 79 & 22.6 \\
Yes & 271 & 77.4 \\
No & 62 & 17.7 \\
Ever had recurrent blisters around your genitals or "private parts" & 82.3 \\
$\quad$ Yes & 288 & \\
No & & 61.7 \\
Ever had cold sores or blisters around the lips or & 216 & 38.3 \\
mouth following an episode of fever & 134 & \\
Yes & & 21.1 \\
No & & 78.9 \\
Virus that causes cold sores or blisters can be & 74 & \\
sexually transmitted & 276 & \\
Yes & & \\
No & & \\
\hline
\end{tabular}

Table 3

Socio-demographic factors influencing the knowledge of genital herpes

\begin{tabular}{|c|c|c|c|c|c|}
\hline Variable & $\begin{array}{l}\text { Never heard of } \\
\text { genital herpes } \\
\text { No. }(\%)\end{array}$ & $\begin{array}{r}\text { Ever } h \\
\text { genital } \\
\text { No. }\end{array}$ & $\begin{array}{l}\text { eard of } \\
\text { herpes } \\
(\%)\end{array}$ & $\begin{array}{c}\text { Yates's } \\
\text { corrected } X^{2} \\
\text { test }\end{array}$ & P-value \\
\hline \multicolumn{6}{|l|}{ Age in years } \\
\hline$\leq 19$ & 10.3 & 0 & 0 & $X^{2}=2.37$ & 0.50 \\
\hline $20-29$ & 9928.3 & 22 & 6.3 & & \\
\hline $30-39$ & 16747.7 & 55 & 15.7 & $\mathrm{Df}=3$ & NS \\
\hline $40-49$ & $5 \quad 1.4$ & 1 & 0.3 & & \\
\hline \multicolumn{6}{|l|}{ Parity } \\
\hline 0 & 0 & 1 & 0.3 & $X^{2}=4.79$ & 0.19 \\
\hline $1-2$ & $156 \quad 44.6$ & 38 & 10.9 & & \\
\hline $3-4$ & 30.6 & 35 & 10 & $\mathrm{Df}=3$ & NS \\
\hline$\geq 5$ & 2.9 & 3 & 0.9 & & \\
\hline \multicolumn{6}{|l|}{ Level of education } \\
\hline Primary & $\begin{array}{ll}8 & 2.3\end{array}$ & 2 & 0.3 & $X^{2}=14.05$ & 0.001 \\
\hline Secondary & $165 \quad 47.1$ & 29 & 8.3 & $\mathrm{Df}=2$ & \\
\hline Tertiary & 28.6 & 47 & 13.4 & & \\
\hline \multicolumn{6}{|l|}{ Occupation } \\
\hline Housewife & 216 & 6 & 1.7 & & \\
\hline Farmer & 20.3 & 1 & 0.3 & $X^{2}=29.77$ & $<0.001$ \\
\hline Trader & $123 \quad 35.1$ & 15 & 4.3 & $\mathrm{Df}=5$ & \\
\hline Student & 19.4 & 16 & 4.9 & & \\
\hline Civil servant & 12.3 & 32 & 9.1 & & \\
\hline Corporate worker & 4.9 & 6 & 1.7 & & \\
\hline
\end{tabular}

$\mathrm{p}=<0.05 \mathrm{NS}=$ Not Significant $\mathrm{Df}=$ Degree of freedom 


\section{DISCUSSION}

In this study, we determined the knowledge of genital herpes infection among antenatal attendees in Aba, South Eastern Nigeria. To the best of our knowledge, no similar study has been conducted in our region.

The study subjects showed a poor knowledge of genital herpes as only $22.6 \%$ of them had ever heard of genital herpes. Further, although $61.7 \%$ of the study subjects self-reported having had cold sores or blisters around the lips or mouth following an episode of fever in the past, thus indicating clinical HSV -1, only $21.1 \%$ knew that the virus that causes cold sores or blisters can be sexually transmitted. The poor knowledge of genital herpes exhibited is despite the fact that the study subjects are relatively educated as $97.5 \%$ of them had attained secondary school education or higher. Results of studies elsewhere also indicate that knowledge about genital herpes is generally poor among both patients and clinicians $(4,5)$. Yet, other studies showed that antenatal populations in the United Kingdom and Australia had a good knowledge of genital herpes $(1,6)$.

The low level of knowledge of genital herpes demonstrated in this study indicates that health education about genital herpes is warranted in the antenatal clinic setting and the contribution of genital herpes to HIV transmission emphasised. Further, education campaigns to raise the level of awareness about genital herpes among the public is also necessary. These public health measures will be most cost effective and beneficial in reducing genital herpes transmission as well as HIV prevention. The alternative preventive and management options of widespread screening for HSV-2 and suppressive antiviral therapy are too expensive to be implemented in the resource restricted sub-Saharan African countries on a large scale.

A study carried out in Coventry, England, among general medical practitioners demonstrated the lack of knowledge in some areas about genital herpes, especially recent information (7). Further, since clinician and patient education is an essential component of management of genital herpes (8), additional research should be conducted to assess health workers' knowledge of genital herpes in our setting. There is a paucity of recommendations or programmes specific to the prevention of genital herpes apart from the standard sexually transmitted infection guidelines worldwide. Until very recently, most sexually transmitted disease interventions have focused on bacterial STIs, which are easier to diagnose and treat than genital herpes. As a result, little attention has been paid to the diagnosis of genital herpes and there has been a lack of prevention interventions; consequently, the epidemics of HSV2 and HIV continue to fuel each other due to the synergistic relationship between ulcerativeSTIs such as genital herpes and the transmission of HIV (9).

In conclusion, the results of this study have shown that the knowledge of genital herpes amongst the antenatal clinic attendees is poor.

We recommended that, discussion of genital herpes should be considered in the antenatal clinic setting along with the counselling of pregnant women regarding genital herpes, HIV infection and maternalto-child transmission of both HSV and HIV. Health education about genital herpes should be offered to the general populace in order to improve the currently low level of awareness of genital herpes.

\section{REFERENCES}

1. Edmiston, N., O'sullivan, M., Charters, D. et al. Study of knowledge of genital herpes infection and attitudes to testing for genital herpes among antenatal clinic attendees. Australia and New Zealand J. Obstet. Gynaecol. 2003; 43: 351-353.

2. Drake, A. L., John-Stewart, G. C., Wald, A., et al. Herpes simplex virus type 2 and risk of intrapartum human immunodeficiency virus transmission. Obstet. Gynae. 2007; 109: 403-409.

3. Gray, R. H., Wawer, M. J., Brookmeyer, R. et al. Probability of HIV-1 transmission per coital act in monogamous, heterosexual, HIV -1 discordant couples in Rakai, Uganda. Lancet. 2001; 357:11491153.

4. Kinghorn, G. R. Limiting the spread of genital herpes. Scand. J. Infect. Dis. 1990; (Suppl 100): 20-25.

5. Handsfield, H. H., Stone, K. M. and Wasserheit, J. N. Prevention agenda for genital herpes. Sex. Transm. Dis. 1999; 26: 228-231.

6. Yonan, B., Low-Beer, N., Barton, S. E. and Smith, J. R. Antenatal serum screening for genital herpes: a study of knowledge and attitudes of women at a central London hospital. Br. J. Obstet. Gynaecol. 1997; 104: 347-349.

7. Narouz, N., Allan, P. S. and Wade, A. H. Genital herpes: general practitioners' knowledge and opinions. Sex Trans. Infect. 2002; 78: 198-200.

8. Narouz, N., Allan, P. S, Wade, A. H. and Wagstaffe, S. Genitalherpes serotyping: astudy of theepidemiology and patients' knowledge and attitude among STD clinic attenders in Coventry, UK. Sex Transm. Inf. 2003; 79: 35-41.

9. Celum, C., Levine, R., Weaver, M. and Wald, A. Genital herpes and human immunodeficiency virus: double trouble. Bull. World Hlth. Org. 2004; 82. 